\title{
Spatio-temporal relationships between habitat types and microbial function of an upland floodplain
}

\author{
Pascal Bodmer ${ }^{1,2} \cdot$ Remo Freimann ${ }^{3,5,6} \cdot$ Stefanie von Fumetti ${ }^{4}$. \\ Christopher T. Robinson ${ }^{5,6} \cdot$ Michael Doering ${ }^{5,7,8}$
}

Received: 6 September 2014/ Accepted: 17 August 2015/Published online: 1 September 2015

(C) Springer Basel 2015

\begin{abstract}
Natural floodplains comprise a spatial mosaic of habitat types that vary in successional development. The physical-chemical properties of soils and sediments in these habitats vary spatio-temporally with changes in hydrology, thereby influencing microbial dynamics and general floodplain functioning. The major goals of this study were to characterize the spatio-temporal variation of different floodplain habitats and elucidate microbial function as a mechanistic basis underlying floodplain functioning. Microbial functional parameters (i.e. soil-sediment
\end{abstract}

Electronic supplementary material The online version of this article (doi:10.1007/s00027-015-0420-9) contains supplementary material, which is available to authorized users.

Pascal Bodmer

bodmer@igb-berlin.de

1 Leibniz-Institute of Freshwater Ecology and Inland Fisheries, Mueggelseedamm 310, 12587 Berlin, Germany

2 Institute of Biology, Freie Universität Berlin, Berlin, Germany

3 Group of Epigenetic Regulation and Cell Identity Control, Institute of Molecular Health Sciences, ETH-Zurich, 8093 Zurich, Switzerland

4 Section of Biogeography, Department of Environmental Sciences, University of Basel, 4056 Basel, Switzerland

5 Eawag, Swiss Federal Institute of Aquatic Science and Technology, 8600 Dübendorf, Switzerland

6 Institute of Integrative Biology, ETH Zurich, 8092 Zurich, Switzerland

7 Institute of Natural Resources Sciences, ZHAW, Zurich University of Applied Sciences, Grüental, 8820 Wädenswil, Switzerland

8 eQcharta GmbH, Ecohydrology in Application, Ueberlandstrasse 129, 8600 Dübendorf, Switzerland respiration, enzyme activity) as well as a microbial state variable (i.e. bacterial abundance, BA) were assessed in conjunction with abiotic properties of respective soils and sediments in different floodplain habitats over an annual cycle. BA and respiration differed significantly among habitat types, being lowest in early successional gravel and stream channel habitats and highest in older successional habitats of mature forest, islands, and riparian pasture/grassland. Coarse-scale floodplain hydrology influenced the spatial variation in microbial measures within specific habitats. A non-metric multidimensional scaling clearly separated habitat types based on the functional activities of eight tested enzymes and specific microbial variables could be linked to soil-sediment respiration. These results document a high functional heterogeneity of soil and sediment microbial variables that complements the shifting habitat mosaic found in most natural floodplains. Moreover, the use of functional measures such as respiration enhances the understanding of complex floodplain functioning.

Keywords Respiration - Enzyme activity - Bacterial abundance . Floodplain habitats $\cdot$ Heterogeneity

\section{Introduction}

Natural riverine floodplains comprise a successional mosaic of different habitats (Stanford et al. 2005; Doering et al. 2012; Datry et al. 2014). Characteristic habitats include early successional stream channels and adjacent gravel bars to later successional habitats such as floodplain islands, floodplain forests, and vegetated riparian zones (Arscott et al. 2002; van der Nat et al. 2003). These habitats differ widely in abiotic properties such as soil and sediment 
texture, temperature, and organic matter content that directly influence biotic assemblages and ecosystem processes (Tonolla et al. 2010; Doering et al. 2011). In natural floodplains, these habitat features are coupled, interconnected and integrated in the floodplain landscape often providing resource subsidies across aquatic/terrestrial ecotones (Nakano and Murakami 2001; Paetzold et al. 2005).

Hydrology, including flow pulses and floods (Junk et al. 1989; Tockner et al. 2000), inherently causes high habitat turnover that maintains the successional habitat mosaic in natural riverine floodplains; a feature known as the 'shifting habitat mosaic' (Stanford et al. 2005). Hyporheic dynamics add another layer of complexity to floodplain heterogeneity, influencing upwelling and downwelling zones at both coarse (floodplain scale) and finer (e.g., heads and tails of riffles) scales (Brunke and Gonser 1997; Boulton et al. 2010). It is likely due to this complexity that most floodplain studies have examined ecosystem processes in so-called terrestrial or aquatic habitats (e.g., Bass et al. 2014, further references in Doering et al. 2011), with only one study that we are aware of that fully linked terrestrial and aquatic habitats in assessing floodplain functioning (i.e. transformation of organic matter and nutrients; Doering et al. 2011). The present study addressed this issue further, using functional measures of soil-sediment microbes (respiration, potential enzyme activities) plus a microbial state variable (bacterial abundance) as indicators of floodplain functioning across different floodplain habitats.

Abiotic properties of soil-sediments, e.g., temperature and moisture, are considered as primary environmental factors controlling key ecosystem processes such as respiration (Davidson et al. 2000; Qi and Xu 2001; Han et al. 2007). Soil-sediment respiration (a term we use here referring to respiration in stream sediments and in terrestrial soil or mixed soil-sediments; sensu Doering et al. 2011) results from the biological metabolism of organic resources and is the primary source of $\mathrm{CO}_{2}$ to the atmosphere (Andrews and Schlesinger 2001). It is defined as $\mathrm{CO}_{2}$ production by autotrophic root respiration, heterotrophic microbial respiration, and respiration of other soilsediment organisms (Buchmann 2000; Hanson et al. 2000). Information on respiration and its regulating factors help towards understanding ecosystem carbon budgets and the response of ecosystems, such as floodplains, to habitat alteration (Buchmann 2000).

Other important soil-sediment properties can directly influence ecosystem metabolism as well (Logue et al. 2004) such as organic matter quality (carbon sources) and soil-sediment chemistry. For instance, upwelling groundwater can be enriched in nitrogen $(\mathrm{N})$ and phosphorous (P) relative to surface waters, in part due to microbial metabolism (i.e. transformation of organic matter) in the hyporheic zone (Grimm and Fisher 1984). A large fraction of respiration in aquatic (Zimmermann et al. 1978; Benner et al. 1995) and terrestrial ecosystems (Singh and Gupta 1977; Hanson et al. 2000) is caused by microbes metabolizing organic matter (Sinsabaugh et al. 1991; Benner et al. 1995). Microbial enzymes are an integral part of processing organic resources (Dick 1994), whereby their activities can vary greatly depending on, e.g., soil type (Stevenson 1986). Hence, potential enzyme activities provide a mechanistic basis underpinning the metabolic activities of microbes in different floodplain habitats. For example, particular microbes increase or decrease enzymes activities in response to organic matter quality and nutrient availability (Romani 2000; Freimann et al. 2013b).

The most widely measured activities of enzymes that catalyze the terminal reactions producing assimilable products from the principal $\mathrm{C}, \mathrm{N}$ and $\mathrm{P}$ sources include $\beta$ glucosidase, $\mathrm{N}$-acetylglucosaminidase, leucine aminopeptidase, and phosphatase (Sinsabaugh et al. 2009). Measuring the potential extracellular enzyme activities under optimal conditions can be used to estimate maximal rates of microbial metabolism and biogeochemical processes (Moorhead and Sinsabaugh 2006; Allison et al. 2007). Furthermore, extracellular enzyme activities can also serve as proxies for substrate supply and related microbial metabolic efforts; i.e. the ratio of a specific enzyme activity to bacterial secondary production (Sieczko and Peduzzi 2014).

The main goal of this study was to determine the spatiotemporal variation between different floodplain habitats in microbial function as a mechanistic basis underlying floodplain functioning. Our specific objectives were (1) to measure respiration, potential enzyme activities, bacterial abundance, and abiotic factors over an annual cycle in five different floodplain habitats (stream, islands, gravel, mature forest, pasture/grassland), and (2) to identify the drivers of respiration within these habitats, and the linkage between respiration and enzyme activities across floodplain habitats. The study was conducted in a pre-alpine upland floodplain in the Swiss Alps that comprises habitat features and hydrology typical of many natural floodplains.

\section{Materials and methods}

\section{Floodplain description and hydrology}

The study floodplain on the Urbach River is located in a prealpine valley (790-910 m a.s.1.) of the Bernese Alps in central Switzerland (Fig. 1). The upland floodplain is $3.4 \mathrm{~km}$ long, up to $600 \mathrm{~m}$ wide, and bounded by geologic knickpoints at both ends. A $1.6 \mathrm{~km}$ high rock face bounds the floodplain to the 


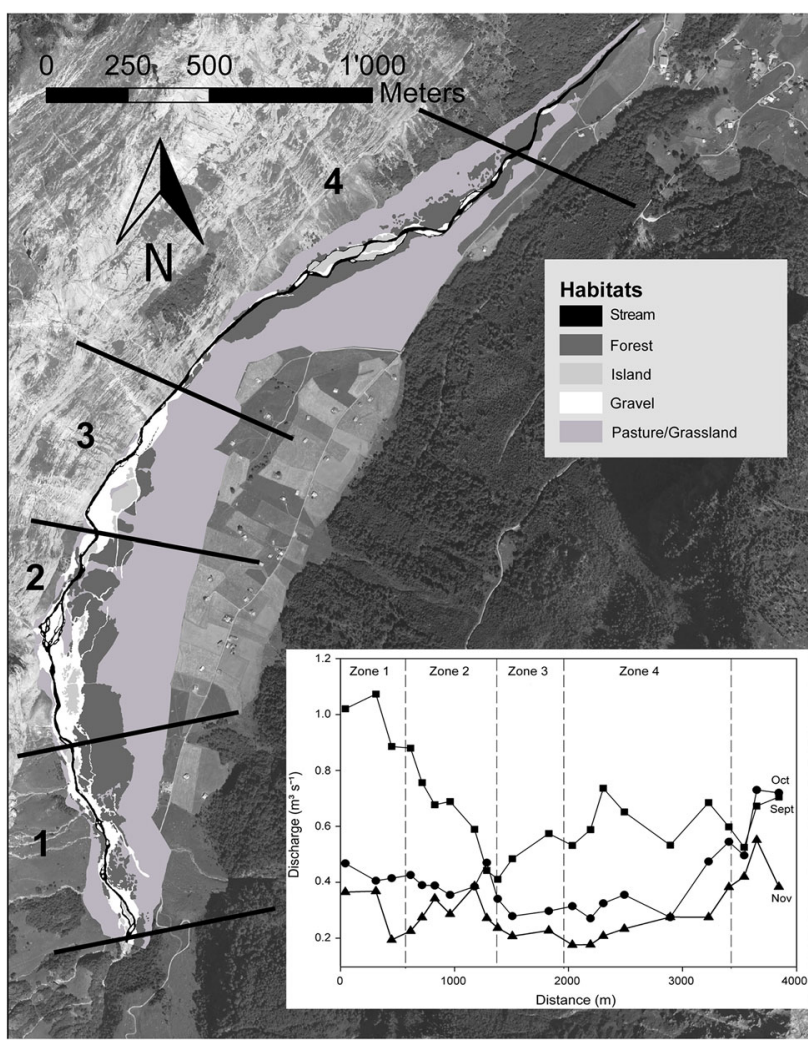

Fig. 1 Overview of the floodplain (source: swisstopo) showing the 4 zones delineated for the study. Inset graph shows the discharge $\left(\mathrm{m}^{3}\right.$ $\mathrm{s}^{-1}$ ) of the river measured in September and November 2009 as well as in October 2010

east, whereas the west side opens into pasture/grassland before transitioning into mountainous side-slopes. Precipitation in the catchment is $1345 \mathrm{~mm}_{\text {year }}{ }^{-1}$ and the average annual air temperature is $8.8^{\circ} \mathrm{C}$. Geology is characterized by limestone and crystalline bedrock.

The Urbach has a near-natural, glacio-nival discharge regime (average discharge $=1.9 \mathrm{~m}^{3} \mathrm{~s}^{-1} ;$ Kraftwerke Oberhasli AG) with highest discharge during snow- and glacier-melt in late spring and summer. Discharge in the river is reduced by about $30 \%$ due to water abstraction at a small headwater reservoir for hydropower production. Several levees for flood protection constrain floodplain morphology along its active tract, although precipitation events cause frequent flow and flood pulses upwards of $6.3 \mathrm{~m}^{3} \mathrm{~s}^{-1}$. These flow events lead to extensive expansion and contraction cycles that create habitats typically found in natural upland floodplains (e.g., gravel bars, floodplain forests, islands). Additional inputs of organic resources to the floodplain are from livestock grazing in local pastures during summer and frequent avalanches off the east-side rock face in winter and early spring.

The study floodplain initially was divided longitudinally into four zones according to coarse-scale geomorphic features and differences in hydrology (Fig. 1;
Robinson and Doering 2012). Zone 1 was at the floodplain head, extending ca. $500 \mathrm{~m}$ downstream, and had mostly downwelling properties [mean vertical hydrological gradient $(\mathrm{VHG})=-0.34]$. VHG is a dimensionless number with positive values indicating upwelling and negative values downwelling conditions. Zone 2 was downstream of zone 1 , being a confined channel segment bordered by the east-side rock face, and had the strongest downwelling of the floodplain (mean $\mathrm{VHG}=-0.45$ ). Zone 3 was located downstream of zone 2 and was a single channel at the upper most upwelling area of the floodplain (mean VHG $=-0.29$ ). Zone 4 was downstream of zone 3 and was a mostly intact floodplain channel with upwelling properties (mean $\mathrm{VHG}=0.06$ ). Longitudinal changes in discharge followed the patterns displayed in VHG between zones with discharge typically decreasing from zone 1 to zone 3 and increasing in zone 4 , being especially evident in the discharge recorded in September (see inset Fig. 1). Within each zone, we selected 5 floodplain habitats: stream, islands, gravel, mature forest, and pasture/grassland for assessment (Table 1). Five sampling sites were randomly selected for each floodplain habitat in each zone by aerial photographs. Soil-sediment measurements were performed at the selected sampling sites in three seasons (May, August, October 2010; $n=100$ per season). Due to the risk of avalanches, a winter sampling was not performed.

\section{Floodplain hydrology}

Discharge was measured at 22 transects sequentially placed along the main channel of the floodplain in September and November 2009 as well as in October 2010 using an acoustic Doppler velocity meter (FlowTracker, SonTek; Lorang et al. 2005). VHG was measured in the main channel as well to determine upwelling and downwelling conditions along the floodplain using piezometers (Baxter et al. 2003). VHG was measured within 2 days in May, July, August, September and October 2010 at 21 sites along the main channel in the floodplain, while the hydrological conditions remained stable during the 2 days of each measurement campaign.

\section{Abiotic factors}

Sampled soil-sediments of each sampling site (i.e. content of collars and tubes sampled after the respiration measurements) were analyzed for water content (WC), organic matter content and grain sizes in the laboratory. WC of soils and sediment samples of islands, mature forest, gravel and pasture/grassland habitats was analyzed gravimetrically $3-12 \mathrm{~h}$ after sampling. Due to high water content, samples were dried at $105{ }^{\circ} \mathrm{C}$ and processed according to 
Table 1 Definitions of floodplain habitats examined in this study

\begin{tabular}{|c|c|}
\hline Habitat type & Definition \\
\hline Stream & $\begin{array}{l}\text { Lotic water body with upstream and downstream connections, i.e. the main channel (van der Nat et al. 2003), characterized } \\
\text { by coarse permeable gravel sediments }\end{array}$ \\
\hline Gravel & $\begin{array}{l}\text { Predominantly terrestrial }{ }^{\mathrm{a}} \text { area characterized by exposed gravel deposits and sparsely and unstable vegetation (such as } \\
\text { different kinds of grasses) }\end{array}$ \\
\hline Islands & $\begin{array}{l}\text { Predominantly terrestrial }{ }^{\mathrm{a}} \text { habitat, mainly colonized by different willow (Salix spp.) species and Alnus incana. These habitats } \\
\text { are surrounded by channel water or exposed gravel (Gurnell et al. 2001), and are characterized by sandy and pebble } \\
\text { substrata and developed soil (Eutrochept fluvisol) }\end{array}$ \\
\hline Pasture/grassland & Predominantly terrestrial $^{\mathrm{a}}$ area of grassland or pasture which are in this study area in the most cases next to the alluvial forest \\
\hline Mature forest & $\begin{array}{l}\text { Predominantly forested terrestrial }{ }^{\mathrm{a}} \text { habitat, characterized by developed soil (Eutrochept fluvisol). The vegetation is mainly } \\
\text { composed of Alnus incana }\end{array}$ \\
\hline
\end{tabular}

a Terrestrial can become partly or completely aquatic habitats during floods

Doering et al. (2011). A certain loss of volatile organic material cannot be ruled out. WC of the stream sediment samples was calculated according to Doering et al. (2011). The organic matter (OM) content of soils and sediments was determined as ash free dry mass by combusting the dried samples $\left(105{ }^{\circ} \mathrm{C}\right)$ at $500{ }^{\circ} \mathrm{C}$ for $3 \mathrm{~h}$ and expressed as $\mathrm{g}$ ash free dry mass (AFDM) $\mathrm{kg}^{-1}$ dry weight (wt). The grain size distribution was determined by sieving the combusted samples to separate the grain size fractions into $<0.063,0.063-2,2-4,4-8$ and $>8 \mathrm{~mm}$ sizes.

\section{Soil-sediment respiration}

Respiration of terrestrial soil-sediment was measured as positive $\mathrm{CO}_{2}$ flux m ${ }^{-2} \mathrm{~s}^{-1}$ using a soil respiration chamber (Li6400, LiCor, USA) attached to a portable Li-6400 infrared gas analyzer (IRGA) set on collars inserted into the soil according to Doering et al. (2011). The soil-sediment enclosed by each collar was collected in a polyvinyl chloride (PVC) bag and transported to the laboratory for additional analyses as described above. Respiration measurements were repeated four times per date and site, and values averaged. Temperature was measured in situ with a temperature probe (Testo $\mathrm{AG}$ ) at $5 \mathrm{~cm}$ depth.

Respiration of stream soil-sediment was measured as oxygen $\left(\mathrm{O}_{2}\right)$ consumption over time of sediments placed in plexiglas tubes (32 cm long, $5.2 \mathrm{~cm}$ diameter) sealed with rubber stoppers (Uehlinger et al. 2002). Sediments $(<8 \mathrm{~mm})$ used for measurement of respiration were collected from channel sites according to methods in Doering et al. (2011). Tubes filled with sediment and stream water (1:1 mix) were incubated in situ in the dark at the corresponding sampling site for at least $4 \mathrm{~h}$. Temperature and oxygen concentration were measured with an HQ40d DualInput Multi-Parameter Digital Meter with a LDO temperature probe (Hach Company, USA) before and after incubation. Sediments of each tube then were placed in plastic bags and stored at $-20{ }^{\circ} \mathrm{C}$ for additional analyses in the laboratory.

Based on the oxygen consumption $r\left(\mathrm{~g} \mathrm{O}_{2} \mathrm{~m}^{-3} \mathrm{~h}^{-1}\right)$ in the water within the tube, respiration per sediment volume $R_{v}$ ( $\left.\mu \mathrm{mol} \quad \mathrm{CO}_{2} \mathrm{~m}^{-3} \mathrm{~s}^{-1}\right)$ was calculated according to Eq. (1):

$R_{v}=r \times \frac{10^{6}}{32} \times \frac{1}{3600} \times \frac{V_{w}}{V_{c}} \times R Q$

where $V_{w}$ is the volume of water in the tube $\left(\mathrm{m}^{3}\right), V_{c}$ the volume of sediment (including porosity) filled into the tube $\left(\mathrm{m}^{3}\right)$ and $R Q$ is the respiratory quotient (0.85; Dilly 2001). The porosity of these sediments was assumed to be $20 \%$ (Doering et al. 2011). To estimate the areal respiration $R\left(\mu \mathrm{mol} \mathrm{CO} \mathrm{CO}_{2} \mathrm{~m}^{-2} \mathrm{~s}^{-1}\right)$ for the upper $20 \mathrm{~cm}$ of the channel sediments, $R_{v}$ was multiplied by $0.2 \mathrm{~m}$ and 0.46 . This factor considers that the metabolic inactive size fraction $>8 \mathrm{~mm}$ (unevenly distributed large stones representing a large part of metabolic inactive substrate) accounted on average $54 \%$ of sediment volume (determined by analyzing 60 gravel samples); thus $R_{v}$ was multiplied by the metabolic active size fraction $<8 \mathrm{~mm}(46 \%)$.

The temperature dependence of respiration is described in Eq. (2):

$y=a \times \exp ^{(b \times \mathrm{T})}$

where $\mathrm{T}$ is the sediment temperature $\left({ }^{\circ} \mathrm{C}\right)$ at $5 \mathrm{~cm}$ depth (terrestrial habitats) or the water temperature in the tube after incubation. Model parameters $a$ and $b$ were identified using nonlinear regression applied to respiration and temperature data of each individual habitat type during the study (see Table $\mathrm{S} 1$ in supplementary material). $\mathrm{Q}_{10}$ values as the increase in reaction rate per $10{ }^{\circ} \mathrm{C}$ increase in temperature (Winkler et al. 1996) were calculated according to Buchmann (2000). For a better comparison of the seasonal results, we calculated respiration at the reference temperature $\left(\mathrm{T}_{\mathrm{r}}\right) 12{ }^{\circ} \mathrm{C}$ according to Eq. (3): 


$$
R\left(\mathrm{~T}_{\mathrm{r}}\right)=\exp ^{b \times\left(\mathrm{T}-\mathrm{T}_{\mathrm{r}}\right)}
$$

It was not possible to apply the same method for measuring respiration in the different habitats in this study. In terrestrial habitats, we measured an area-specific $\mathrm{CO}_{2}$ flux, while minimizing disturbance of the area of measurement. In stream habitats, we measured sediment respiration as changes in $\mathrm{O}_{2}$ concentration over time in sealed Plexiglas cores (after Jones et al. 1995). The application of these two different methods may lead to some extent to a constrained comparability among habitats. However, the measurements provide a first estimate of spatio-temporal heterogeneity of respiration across different floodplain habitats. For a detailed discussion of the two applied methods see Doering et al. (2011).

\section{Microbial variables}

The collected soil-sediment $<8 \mathrm{~mm}$ (ca. $50 \mathrm{~g}$, including pore water for stream samples to account for fine material) was used to estimate bacterial abundance and enzyme activity for the different habitat types. The metabolically inactive soil-sediment size fraction $>8 \mathrm{~mm}$ was excluded and plant debris and roots were removed to exclude enzymes expressed by phytobiota. Dry weight (dry wt) was determined as described above to express bacterial abundance per $\mathrm{g}$ dry wt of soil-sediment.

Within $24 \mathrm{~h}$ of collection, $\sim 3 \mathrm{~g}$ of soil-sediment were fixed in a $10 \mathrm{~mL} 2 \%$ paraformaldehyde (PFA) and $0.1 \%$ sodium pyrophosphate mix $\left(20 \mathrm{~g} \mathrm{~L}^{-1} \mathrm{PFA}\right.$ and $1 \mathrm{~g} \mathrm{~L}^{-1}$ sodium pyrophosphate) and stored at $4{ }^{\circ} \mathrm{C}$. Within 4-6 weeks, the fixed samples were processed and analyzed. This treatment was applied to all samples. Although the absolute number of cells was possibly reduced due to extended storage in PFA (Parvathi et al. 2011), the procedure should still enable us to compare the bacterial abundance among the different habitats. Physical detachment of bacterial cells from the soil-sediment was performed by sonification [38 watt (W) for $60 \mathrm{~s}$, flat tip (13 mm), Branson Digital Sonifier 250]. In respect to data comparability, only one cell detachment process was chosen. The relatively harsh extraction procedure with the ultrasonic probe and the $60 \mathrm{~s}$ treatment was chosen as an appropriate method to handle the wide range of substrate types in this study (Buesing and Gessner 2002). After homogenization, a 1-mL subsample of the bacterial cell suspension was pipetted to a $0.5 \mathrm{~mL}$ Histodenz ${ }^{\circledR}$ solution (1.3 $\mathrm{g} \mathrm{mL}^{-1}$, Sigma-Aldrich). Samples were then centrifuged $\left(90 \mathrm{~min}\right.$ at $\left.4{ }^{\circ} \mathrm{C}, 1700 \times g\right)$ to separate bacterial cells from soil-sediment particles. The supernatant containing the bacterial cells was used for further analysis.

Each supernatant sample was diluted 100 times with filtered $\left(0.22 \mu \mathrm{m}\right.$ Millex $^{\circledR}$-GP, Millipore $)$ mineral water
(Evian, France) and then stained with $10 \mu \mathrm{L} \mathrm{SYBR}{ }^{\circledR}$ Green I or Gel Star [Cambrex, 1-100 dilution in dimethyl sulfoxide (DMSO)], incubated for $10 \mathrm{~min}$, and again diluted 100 times. Preliminary tests using flow cytometry showed no significant differences in detection rate of cells between the two stains. Samples were counted using a Particle Analyzing System (PAS) III flow cytometer (Partec GmbH, Germany) equipped with a $25 \mathrm{~mW}$ solid-state laser, emitting at a fix wavelength of $488 \mathrm{~nm}$. Green fluorescence was collected in the fluorescence (FL-) channel 1 $(530 \pm 30 \mathrm{~nm})$ and red fluorescence in the FL3 channel (>590 nm) (Hammes and Egli 2005). The flow cytometer instrumental gain settings were adjusted as follows: FL1 $=550$, FL3 $=801$, speed $=4$. Data were processed with Flowmax software (Partec GmbH, Germany) using a standardized electronic gate at the FL1-FL3 scatterplot to separate the microbial cells from the instrument noise and sample background. The results of the scatterplot were bacterial cell counts (i.e. bacterial abundance) which were rounded to thousands and standardized to the dry weight of the initial soil-sediment sample.

Eight enzymes that provide insight into microbial C, N and $\mathrm{P}$ acquisition were used for the assays (Table 2). Samples for analysis of enzyme activity were stored frozen at $-20{ }^{\circ} \mathrm{C}$ and measured by using methylumbelliferone (MUF) labeled substrates. The effect of freezing on enzyme activities is thought to be minor (Wallenius et al. 2010). The fluorometric enzyme assays were performed as follows: $5-10 \mathrm{~g}$ of sediment sample $(5 \mathrm{~g}$ for islands, pasture/grassland and mature forest samples, $7 \mathrm{~g}$ for gravel samples, $10 \mathrm{~g}$ for stream sediment samples, depending on the expected enzyme activity intensities in the different habitats) were mixed with $20 \mathrm{~mL}$ of autoclaved Milli-Q ultrapure water (MQ) and vortexed for $1 \mathrm{~min}$. Then, $150 \mu \mathrm{L}$ of the suspended samples and $100 \mu \mathrm{L}$ of substrate analogue (final substrate concentration $=400 \mu \mathrm{mol} \mathrm{L}{ }^{-1}$ ) were pipetted into a 96 well plate. Substrate analogues were buffered in bicarbonate or in MQ, respectively. Substrate blanks (MUF-substrate plus buffer) were used to assess sample specific quenching due to different suspension colors by adding $50 \mu \mathrm{L}$ of a $100 \mu \mathrm{mol} \mathrm{L}^{-1}$ free MUF solution to the blanks and corresponding samples. The ratio between blank and sample fluorescence increase was then used as a quenching correction factor. A standard curve was used to convert fluorescence to quantity of MUF released. Fluorescence was measured with a microplate reader (Tecan Infinite ${ }^{\circledR} 200$, Switzerland) at an excitation wavelength of $365 \mathrm{~nm}$ and an emission wavelength of $450 \mathrm{~nm}$. Three measurements were performed $10 \mathrm{~min}$ to $1 \mathrm{~h}$ after the addition of the substrates to detect the more active enzymes and two after $15-20 \mathrm{~h}$ to detect the less active ones. Microplates were incubated on a shaker at $15{ }^{\circ} \mathrm{C}$ in the dark between measurements according to 
Table 2 Enzymes analyzed in this study, substrate used for assays and their biogeochemical functions

\begin{tabular}{|c|c|c|c|c|}
\hline Enzyme (abbreviation) & Substrate analogue & $\begin{array}{l}\text { Acquiring } \\
\text { element }\end{array}$ & Target & Function in ecosystem \\
\hline$\alpha$-Glucosidase (ALPH) & 4-MUF- $\alpha$-D-glucoside & Carbon & $\alpha-1,4-$ and 1,6 -glucosidic linkages & Starch degradation \\
\hline$\beta$-Glucosidase (BET) & 4-MUF- $\beta$-D-glucoside & Carbon & $\beta$-1,4-Glucans & Cellulose degradation \\
\hline$\beta$-Xylosidase (XYL) & 4-MUF- $\beta$-D-xylopyranoide & Carbon & Xylose residues & $\begin{array}{l}\text { Hemicellulose } \\
\text { degradation }\end{array}$ \\
\hline Esterase (EST) & 4-MUF-acetate & Carbon & Small ester containing molecules & Glyceride hydrolization \\
\hline $\begin{array}{l}\text { N-Acetyl-glucosaminidase } \\
\text { (NAC) }\end{array}$ & $\begin{array}{l}\text { 4-MUF-N-acetyl- } \beta \text {-D- } \\
\text { glucosaminide }\end{array}$ & Nitrogen & $1,4-\beta$-Linkages of glucosamines & Chitin degradation \\
\hline $\begin{array}{l}\text { Leucine-aminopeptidase } \\
\text { (LEU) }\end{array}$ & $\begin{array}{l}\text { L-Leucine-7-amido-4- } \\
\text { methylcoumarin }\end{array}$ & Nitrogen & $\begin{array}{l}\text { Hydrophobic amino acids from } \mathrm{N} \\
\text { terminus }\end{array}$ & Peptide degradation \\
\hline Endopeptidase (END) & 4-MUF-4-guanadinoenzoate & Nitrogen & Peptide bonds & Peptide degradation \\
\hline Phosphatase (PHOS) & 4-MUF-phosphate & Phosphorous & Phosphomono and diester & $\begin{array}{l}\text { Protein, nucleotide } \\
\text { degradation }\end{array}$ \\
\hline
\end{tabular}

existing protocols (Freimann et al. 2013b). Enzyme activities were standardized to nmol substrate $\mathrm{h}^{-1} \mathrm{~g} \mathrm{AFDM}^{-1}$.

\section{Statistical analysis}

We applied a two-way analysis of variance (ANOVA) to test for differences in respiration, bacterial abundance, and specific enzyme activity (dependent variables) among habitat types and seasons (independent variables). Then we used a one-way ANOVA to test for differences in respiration (dependent variable) in single habitat types between zones (independent variable). ANOVAs with significant main effects were followed by Scheffé post hoc tests (Zar 1984). All data were log-transformed to meet the assumption of normality prior to running ANOVA. A nonparametric Spearman rank correlation was used to determine relationships between respiration and abiotic factors and bacterial abundance. We used principal components analysis (PCA) to estimate the proportion of variation in habitat diversity that was associated with specific environmental variables (Clarke and Gorley 2006).

We tested relationships of respiration standardized to $12{ }^{\circ} \mathrm{C}$ and enzymatic activities using multiple linear regression. The model was forward-selected by Aikaike's Information Criterion (AIC) and the significance of single enzymes was tested by permutation ANOVA (Type III SS). The relative importance of predictors in this linear model and the explained variation was assessed using the lmgmetric (Chevan and Sutherland 1991; Grömping 2006). We performed a non-parametric multidimensional scaling (NMDS) of enzymatic activities in combination with factor fitting to assess the enzymatic structural patterns of different habitat types and visualized as dispersion ellipses in the NMDS ordination. The significance of fitted factors was tested by a permutation test (999 permutations).
Generalized additive models (GAM; thin plate splines) for respiration standardized to $12{ }^{\circ} \mathrm{C}$ and physical-chemical variables were fitted to the first two dimensions of the NMDS plot. This allows assessment of the overall relationship of the enzymatic activity pattern to respiration and single environmental variables (Bennion et al. 2011). Additionally, a redundancy analysis (RDA) of the enzymatic activities including forward-selected model variables was performed to assess the relative contribution of the variables to the explained variation on single RDA axis. NMDS and RDA analysis were based on enzymatic activities standardized to AFDM. Statistical modeling was performed with the Statistical Package for Social Sciences (SPSS) version 18.0 for windows (SPSS Inc.) and R (RDevelopment-Core-Team 2014).

\section{Results}

\section{Abiotic characteristics of floodplain habitats}

The water content (mean $\pm 1 \mathrm{SD}$, as \%WC) of soil-sediments was highest in mature forest $(31.8 \pm 12.4 \% \mathrm{WC})$ and pasture/grassland $(35.5 \pm 9.9 \% \mathrm{WC})$ habitats, and lowest in stream $(9.8 \pm 0.5 \% \mathrm{WC})$ and gravel $(2.3 \pm 2.2 \% \mathrm{WC})$ habitats (Scheffé test $p<0.05$ ) (Table 3 ). The amount of organic matter associated with soil-sediments also was highest in mature forest $\left(141.3 \pm 88.4 \mathrm{~g} \mathrm{AFDM} \mathrm{kg}^{-1}\right.$ dry wt $)$ and pasture/grassland $\left(151.8 \pm 77.6 \mathrm{~g}\right.$ AFDM kg ${ }^{-1}$ dry wt) habitats, and lowest in stream $\left(3.4 \pm 1.0 \mathrm{~g} \mathrm{AFDM} \mathrm{kg}^{-1}\right.$ dry wt) and gravel $\left(4.2 \pm 2.3 \mathrm{~g} \mathrm{AFDM} \mathrm{kg}^{-1}\right.$ dry wt) habitats $(p<0.05)$. Islands had intermediate values for both variables $\left(21.6 \pm 13.1 \% \mathrm{WC}, 71.9 \pm 71.6 \mathrm{~g} \mathrm{AFDM} \mathrm{kg}^{-1} \mathrm{dry} \mathrm{wt}^{-1}\right)$. Sediment grain size $>8 \mathrm{~mm}$ ranged from $6.3 \pm 13.2 \%$ in mature forest habitat to $54.4 \pm 21.1 \%$ in gravel habitats, 
Table 3 Abiotic characteristics of soil-sediments in examined floodplain habitats

\begin{tabular}{|c|c|c|c|c|c|}
\hline Variable & Stream $n=60$ & Gravel $n=60$ & Islands $n=60$ & Pasture/grassland $n=60$ & Mature forest $n=60$ \\
\hline $\mathrm{WC}(\%)$ & $9.8 \pm 0.5$ & $2.3 \pm 2.2$ & $21.6 \pm 13.1$ & $35.5 \pm 9.9$ & $31.8 \pm 12.4$ \\
\hline Temperature $\left({ }^{\circ} \mathrm{C}\right)$ & $9.2 \pm 3.6$ & $15.8 \pm 8.8$ & $12.4 \pm 5.7$ & $13.6 \pm 6.2$ & $11.7 \pm 4.5$ \\
\hline $\mathrm{OM}<2 \mathrm{~mm}\left(\mathrm{~g} \mathrm{AFDM} \mathrm{kg}^{-1}\right.$ dry wt $)$ & $2.1 \pm 0.7$ & $2.3 \pm 1.1$ & $21.7 \pm 27.9$ & $24.8 \pm 29.0$ & $38.7 \pm 50.0$ \\
\hline $\mathrm{OM}>2 \mathrm{~mm}\left(\mathrm{~g} \mathrm{AFDM} \mathrm{kg}^{-1}\right.$ dry wt $)$ & $1.3 \pm 0.6$ & $1.9 \pm 1.9$ & $50.2 \pm 47.5$ & $127.0 \pm 65.9$ & $102.6 \pm 57.5$ \\
\hline OM total (g AFDM kg ${ }^{-1}$ dry wt) & $3.4 \pm 1.0$ & $4.2 \pm 2.3$ & $71.9 \pm 71.6$ & $151.8 \pm 77.6$ & $141.3 \pm 88.4$ \\
\hline $\mathrm{GS}>8 \mathrm{~mm}(\%)$ & $54.4^{\mathrm{a}}$ & $54.4 \pm 21.1$ & $9.3 \pm 15.4$ & $8.6 \pm 15.5$ & $6.3 \pm 13.2$ \\
\hline GS $8-4 \mathrm{~mm}(\%)$ & $17.9 \pm 4.7^{\mathrm{b}}$ & $11.5 \pm 4.9$ & $4.0 \pm 7.0$ & $2.3 \pm 2.4$ & $2.4 \pm 3.9$ \\
\hline GS $4-2 \mathrm{~mm}(\%)$ & $13.7 \pm 2.0^{\mathrm{b}}$ & $8.5 \pm 5.0$ & $3.8 \pm 3.9$ & $3.1 \pm 3.4$ & $2.9 \pm 4.9$ \\
\hline GS $2-0.063 \mathrm{~mm}(\%)$ & $13.9 \pm 4.9^{\mathrm{b}}$ & $25.1 \pm 17.4$ & $80.6 \pm 21.3$ & $83.4 \pm 17.6$ & $86.3 \pm 19.1$ \\
\hline $\mathrm{GS}<0.063 \mathrm{~mm}(\%)$ & $0.1 \pm 0.1^{\mathrm{b}}$ & $0.4 \pm 0.4$ & $2.4 \pm 2.0$ & $2.6 \pm 1.6$ & $2.1 \pm 1.7$ \\
\hline
\end{tabular}

Mean \pm 1 SD values were calculated from pooled data of May, August and October 2010. Water content (WC) is expressed as \% of dry weight (dry wt), soil-sediment temperature was taken in situ and refers in the stream habitat to water temperature, organic matter (OM) content of two size fractions and total content as $\mathrm{g}$ AFDM kg ${ }^{-1}$ dry wt, and classes of grain size distribution (GS) are expressed in $\%$ of the sum of all size fractions

$n$ number of samples in each habitat

${ }^{\text {a }}$ Values adopted from the analysis of 60 gravel samples

b Values recalculated after adoption of $54.44 \%$ to GS $>8 \mathrm{~mm}(\%)$ from the gravel habitat

whereas the grain size fraction $2-0.063 \mathrm{~mm}$ ranged from $25.1 \pm 17.4 \%$ in gravel habitats to $86.3 \pm 19.1 \%$ in mature forests. Soil-sediment temperatures were lowest in stream $\left(9.2 \pm 3.6{ }^{\circ} \mathrm{C}\right)$ and highest in gravel $\left(15.8 \pm 8.8^{\circ} \mathrm{C}\right)$ habitats (Table 3).

PCA analysis based on these physical characteristics clearly separated the stream and gravel habitats from the mature forest, islands and pasture/grassland habitats (Fig. 2). PCA axis-1 and axis-2 explained 80 and $11 \%$ of the total variance, respectively. Axis- 1 was best defined by the different grain sizes, organic matter, and water content, whereas axis- 2 was best defined by temperature. Stream and gravel habitats were situated more to the left on axis-1, reflecting the coarser grain size proportion, lower amounts of organic matter and lower \%WC relative to mature forest, islands and pasture/grassland habitats.

\section{Respiration in floodplain habitats}

Respiration (temperature uncorrected values) differed significantly between habitats with stream and gravel habitats exhibiting lower values than mature forest, islands and pasture/grassland habitats $\left[F_{(4)}=418.83\right.$, Scheffé test $p<0.001$ ] (Fig. 3a). Respiration was lowest in stream habitats $\left[0.12 \pm 0.07 \mu \mathrm{mol} \mathrm{CO} \mathrm{m}^{-2} \mathrm{~s}^{-1}\right.$, mean \pm 1 standard deviation (SD)] and highest in pasture/grassland $\left(4.31 \pm 2.54 \mu \mathrm{mol} \mathrm{CO} \mathrm{CO}_{2} \mathrm{~m}^{-2} \mathrm{~s}^{-1}\right)(p<0.05)$. Seasonally, respiration ranged from $0 \mu \mathrm{mol} \mathrm{CO}_{2} \mathrm{~m}^{-2} \mathrm{~s}^{-1}$ (below the analytical detection limits) in gravel habitats in October to $6.22 \pm 2.07 \mu \mathrm{mol} \mathrm{CO} \mathrm{CO}_{2} \mathrm{~m}^{-2} \mathrm{~s}^{-1}$ in pasture/grassland in May. Respiration was significantly higher in May

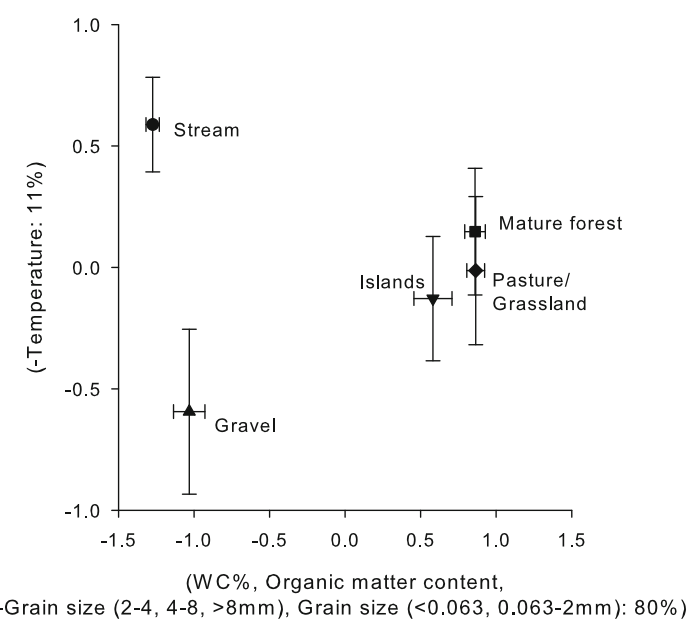

Fig. 2 Scatterplot of the results from a principal component analysis based on abiotic factors of soil-sediments measured in the different floodplain habitats. Symbols show means of 60 values per habitat $\pm \mathrm{SE}$ of factor scores for samples collected in May, August and October 2010 along the two primary axes. Abiotic factors (\%WC percent water content, organic matter content as $\mathrm{g}$ AFDM kg ${ }^{-1}$ dry wt, sediment grain sizes $>8,8-4,4-2$ and $2-0.063 \mathrm{~mm}$ as $\%$ of the sum of all size fractions, in situ soil-sediment temperature) labeling each axis had factor loads of 0.90 or higher for that axis, the algebraic sign is for the variable factor loading

(pasture/grassland, stream, gravel) and August (mature forest, islands) than in October $\left[F_{(2)}=12.25, p<0.001\right]$.

Temperature corrected respiration (at $12{ }^{\circ} \mathrm{C}$ ), which allows a better comparability, displayed a similar pattern as uncorrected values (see Fig. S1 in supplementary material). Respiration differed significantly between habitats 

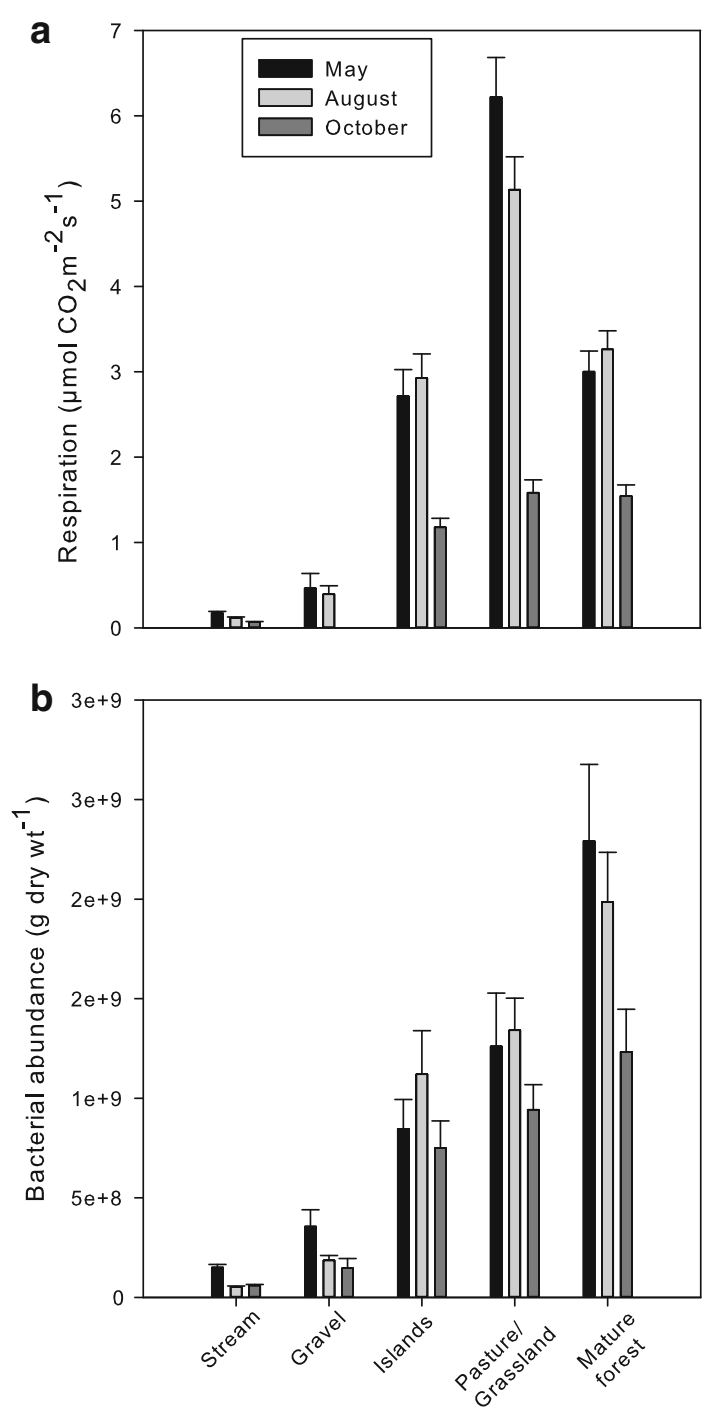

Fig. 3 Mean $( \pm \mathrm{SE})$ temperature uncorrected respiration (a) and bacterial abundance expressed as cells per g dry weight (b) of soilsediments in the different floodplain habitats in May, August, and October. $n=20$ per habitat type and month

$\left[F_{(4)}=588.84\right.$, Scheffé test $\left.p<0.001\right]$, ranging from $0.01 \pm 0.03 \mu \mathrm{mol} \mathrm{CO}_{2} \mathrm{~m}^{-2} \mathrm{~s}^{-1}$ in gravel habitats to $3.14 \pm 1.20 \mu \mathrm{mol} \quad \mathrm{CO}_{2} \mathrm{~m}^{-2} \mathrm{~s}^{-1}$ in pasture/grassland habitats. In general, respiration was highest in May (August for islands at $2.31 \pm 0.99 \mu \mathrm{mol} \mathrm{CO} \mathrm{CO}^{-2} \mathrm{~s}^{-1}$ ) and lowest in October $\left[F_{(2)}=4.94, p=0.008\right]$. Temperature corrected respiration $\left(12{ }^{\circ} \mathrm{C} ; \mu \mathrm{mol} \mathrm{CO}_{2} \mathrm{~m}^{-2} \mathrm{~s}^{-1}\right)$ per $\mathrm{kg}$ AFDM ranged from $50.70 \pm 35.83$ (island habitats) to $1.28 \pm 5.98$ (gravel habitats). The differences between habitat types were significant $\left[F_{(4)}=293.76, p<0.001\right]$, and the Scheffé post hoc test indicated significant differences between the gravel and all other habitats, whereas mature forest and pasture/grassland did not statistically differ $(p=0.93)$. Seasonal differences in temperature corrected respiration per $\mathrm{kg}$ AFDM were significant
$\left[F_{(2)}=5.35, p=0.005\right]$ as a result of significant higher respiration rates in May compared to October. Temperature corrected respiration was significantly higher in zone 4 than the other zones for islands $(p<0.001)$, whereas the other floodplain habitats had similar respiration values between zones (see Fig. S2a in supplementary material). The $\mathrm{Q}_{10}$ values ranged from 1.91 for island habitats to 2.73 for pasture/grassland habitats (see Table $\mathrm{S} 1$ in supplementary material).

\section{Bacterial abundances in floodplain habitats}

Bacterial abundance (BA) differed significantly between habitats $\left[F_{(4)}=182.28\right.$, Scheffé test $\left.p<0.001\right]$ with highest values in mature forest and pasture/grassland habitats $(p<0.001)$ (Fig. 3b). Bacterial abundances ranged from $8.7 \times 10^{7} \pm 6.2 \times 10^{7} \mathrm{BA} \mathrm{g} \mathrm{dry} \mathrm{wt}{ }^{-1}$ (mean \pm 1 $\mathrm{SD})$ in stream habitats to $2.3 \times 10^{9} \pm 1.72 \times 10^{9} \mathrm{BA}$ g dry $\mathrm{wt}^{-1}$ in mature forests. Bacterial abundance differed significantly between months $\left[F_{(2)}=13.49, p<0.001\right]$ with values in May and August being significantly higher than in October $(p<0.05)$. Seasonally, abundances varied from $5.2 \times 10^{7} \pm 2.4 \times 10^{7}$ in August to $1.5 \times 10^{8} \pm 6.9 \times 10^{7}$ BA g dry wt ${ }^{-1}$ in May in the gravel habitats $\left[F_{(2)}=10.25\right.$, $p<0.001]$ and from $1.2 \times 10^{9} \pm 9.6 \times 10^{8}$ in October to $2.0 \times 10^{9} \pm 1.1 \times 10^{9} \mathrm{BA} \mathrm{g} \mathrm{dry} \mathrm{wt}{ }^{-1}$ in May in mature forests $\left[F_{(2)}=4.78, p=0.013\right]$. The variation in bacterial abundance was high within habitats, resulting in some differences between zones for some habitats (see Fig. S2b in supplementary material). For instance, low abundances were found in zone 3 for islands and for mature forests in zone 2, whereas gravel habitats had highest abundances in zone $3(p<0.05)$. No differences were found between zones for stream and pasture/grassland habitats.

\section{Enzyme activity in floodplain habitats}

NMDS analysis using the activities of 8 enzymes clearly separated habitat types, except for pasture/grassland and mature forest habitats which were grouped together (Fig. 4; Table 4). The NMDS revealed that stream and gravel habitats were mainly associated with esterase (EST) and endopeptidase (END) activity, whereas the mature forest and pasture/grassland habitats were defined by $\mathrm{N}$-acetylglucosaminidase (NAC), xylosidase (XYL), $\beta$-glucosidase (BET) and phosphatase (PHOS) activity. Leucineaminopeptidase (LEU) and $\alpha$-glucosidase (ALPH) were strongly associated with island habitats (Fig. 4). Seasonal shifts in enzymatic activity patterns were visible for stream and gravel habitats (factor fitting: $\mathrm{r}^{2}=0.77, p<0.001$, see Fig. S3 in supplementary material). Zone 4 exhibited different activities for END, NAC, PHOS and EST (Scheffé test, $p<0.05$ ), whereas LEU, ALPH, BET and XYL showed no differences in zone 4 compared to the 


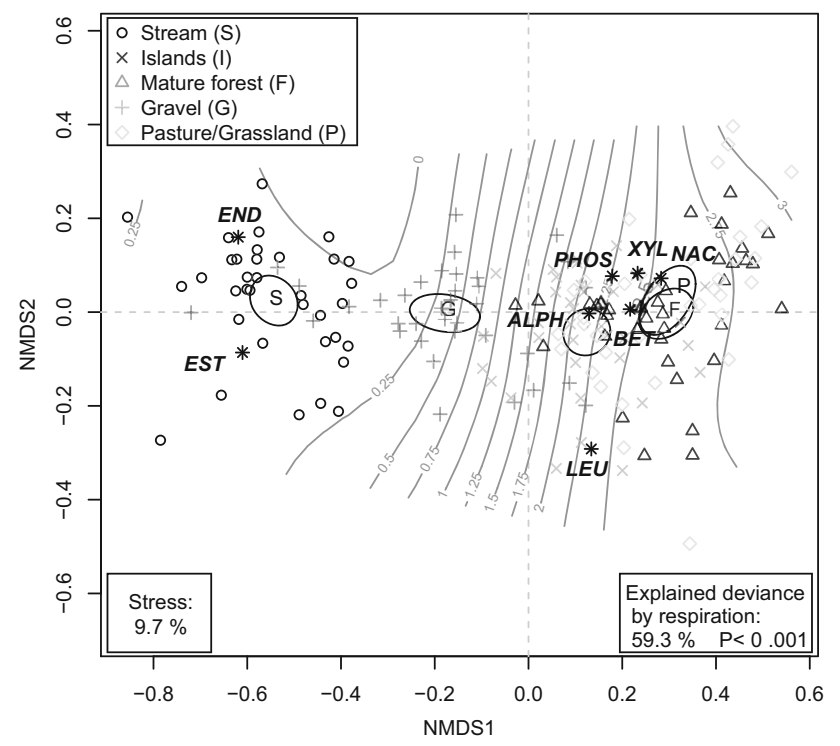

Fig. 4 Non-metric multidimensional scaling (NMDS) based on enzymatic activities standardized to AFDM. The response variable centroids (i.e. enzymes) are depicted with an asterisk. Dispersion ellipses depict the standard errors of weighted average scores of habitat groupings (confidence limits $=0.95$ ). Additionally, a generalized additive model for respiration standardized to $12{ }^{\circ} \mathrm{C}$ is fitted to the first two dimensions of the NMDS plot

Table 4 (a) Explained deviation (Dev) of the response surface (generalized additive models) of the environmental variables, and (b) fitted factors with their squared correlation coefficients $\left(\mathrm{r}^{2}\right)$ on the enzyme non-metric multidimensional scaling (NMDS)

\begin{tabular}{|c|c|c|c|c|c|}
\hline \multirow{2}{*}{$\begin{array}{l}\text { (a) } \\
\text { Variable }\end{array}$} & & \multicolumn{4}{|l|}{ NMDS } \\
\hline & & $d F$ & $F$ & $\operatorname{Dev}(\%)$ & $p$ \\
\hline \multicolumn{2}{|l|}{ WC (\%) } & 10.17 & 2.55 & 60.9 & $<0.001$ \\
\hline \multicolumn{2}{|c|}{ Temperature } & 5.80 & 0.11 & 9.0 & $<0.05$ \\
\hline \multicolumn{2}{|c|}{ Respiration $\left(\mu \mathrm{mol} \mathrm{CO} \mathrm{C}^{-2} \mathrm{~s}^{-1}\right)$} & 8.76 & 2.42 & 59.3 & $<0.001$ \\
\hline \multicolumn{2}{|c|}{$\mathrm{BA}\left(\right.$ cells $\mathrm{g}^{-1}$ dry wt) } & 6.08 & 1.05 & 33.5 & $<0.001$ \\
\hline \multicolumn{2}{|c|}{$\mathrm{GS}>8 \mathrm{~mm}$} & 8.41 & 1.36 & 45.2 & $<0.001$ \\
\hline \multicolumn{2}{|c|}{ GS 4-8 mm } & 14.25 & 5.91 & 78.6 & $<0.001$ \\
\hline \multicolumn{2}{|c|}{ GS 2-4 mm } & 20.9 & 6.84 & 81.7 & $<0.001$ \\
\hline \multicolumn{2}{|c|}{ GS $0.063-2 \mathrm{~mm}$} & 14 & 3.73 & 70.2 & $<0.001$ \\
\hline \multicolumn{2}{|c|}{$\mathrm{GS}<0.063 \mathrm{~mm}$} & 5.68 & 2.91 & 52.0 & $<0.001$ \\
\hline (b) Factor & $\mathrm{r}^{2}$ & \multicolumn{4}{|l|}{$p$} \\
\hline Zone & 0.02 & \multicolumn{4}{|l|}{0.31} \\
\hline $\begin{array}{c}\text { Habitat } \\
\text { type }\end{array}$ & 0.73 & \multicolumn{4}{|c|}{$<0.001$} \\
\hline Month & 0.02 & \multicolumn{4}{|l|}{0.17} \\
\hline
\end{tabular}

Water content (WC) is expressed as \% of dry weight (dry wt), soilsediment temperatures were measured in situ, respiration is standardized to $12{ }^{\circ} \mathrm{C}$, bacterial abundance (BA) is expressed as cells per $\mathrm{g}$ dry wt, and classes of grain size distribution (GS) are expressed in arcsine square root transformed $\%$ of the sum of all size fractions other zones. Most of the zonal differences were attributed to islands and mature forest habitats.

\section{Potential drivers of respiration and enzyme activities}

Soil-sediment respiration was significantly correlated with temperature in all habitat types $(r=0.44-0.76, p<0.001)$ (Table 5). Respiration in all habitats except pasture/grassland also was significantly correlated with bacterial abundance $(r=0.27-0.47, p<0.05)$, although to a lesser degree than with temperature. Respiration in stream habi-

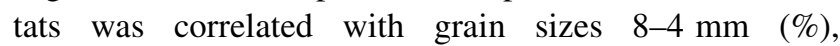
$2-0.063 \mathrm{~mm}$, and $<0.063 \mathrm{~mm}(p<0.001)$. Respiration in all habitats except pasture/grassland was correlated with various fractions of organic matter (islands $\mathrm{OM}<2 \mathrm{~mm}$ and total OM; stream, gravel, mature forest $\mathrm{OM}>2 \mathrm{~mm}$ ). Enzymatic activity patterns were correlated via GAM with WC (60.9\%), grain sizes (45.2-81.7\%) and temperature (9.0\%) (Table 4). Respiration as well as bacterial abundance correlated with the overall enzymatic activity pattern (59.3 and $33.5 \%$, respectively; Table 4; Fig. 4). The selected variable in the RDA model explained $48.9 \%$ of the variation. Some $37.6 \%$ was accounted on the first RDA axis by WC, temperature and grain sizes $<0.063,2-0.063$ and 4-2 mm, which explained 9.8, 1.4, 16.8, 2.9 and $6.7 \%$ of the variation, respectively. Multiple linear regression (MLR) revealed a strong negative correlation of respiration with END and ALPH activity (68.2 and $10.6 \%$, respectively, $p<0.01$ ), whereas BET and LEU activities were positively correlated (7.6 and $2.7 \%$, respectively, $p<0.05)$. The analysis via MLR revealed that $53.8 \%$ of the variance of respiration can be explained by enzyme activities.

\section{Discussion}

Respiration rates were substantially higher in floodplain habitats of islands, mature forest and pasture/grassland than in stream and gravel habitats. Respiration was highest in mature forest and pasture/grassland habitats; the latter being as high as in soils of a Southeast Asian tropical rainforest (Kosugi et al. 2007). Gravel and stream habitats were dominated by large soil-sediment grain sizes and low amounts of organic matter, whereas the other habitats had a predominance of small soil-sediment grain sizes and high amounts of organic matter. The relatively high quantity of organic matter may explain the high respiration in some floodplain habitats (see Doering et al. 2011). Nutrient input from livestock also may explain the high respiration rates in pasture/grassland habitats (Iovieno et al. 2009), although an opposite effect also has been shown (Kastovska et al. 
Table 5 Spearman rank correlations ( $\mathrm{r}$ values) of soil-sediment respiration $\left(\mu \mathrm{mol} \mathrm{CO}_{2} \mathrm{~m}^{-2} \mathrm{~s}^{-1}\right.$ ) and abiotic factors and bacterial abundance (BA) expressed as cells per g dry weight (dry wt) (pooled data of three seasons)

\begin{tabular}{|c|c|c|c|c|c|}
\hline Independent variable & Stream $n=59$ & Gravel $n=60$ & Islands $n=60$ & Pasture/grassland $n=59$ & Mature forest $n=60$ \\
\hline $\mathrm{WC}(\%)$ & -0.105 & -0.204 & 0.042 & 0.060 & 0.223 \\
\hline $\mathrm{OM}<2 \mathrm{~mm}\left(\mathrm{~g} \mathrm{AFDM} \mathrm{kg}^{-1}\right.$ dry wt $)$ & -0.179 & -0.035 & $0.308^{*}$ & 0.037 & 0.192 \\
\hline $\mathrm{OM}>2 \mathrm{~mm}\left(\mathrm{~g} \mathrm{AFDM} \mathrm{kg}^{-1}\right.$ dry wt $)$ & $0.425^{*}$ & $0.447 *$ & 0.222 & 0.150 & $0.258^{*}$ \\
\hline OM total (g AFDM kg ${ }^{-1}$ dry wt) & 0.121 & 0.235 & $0.268 *$ & 0.127 & 0.210 \\
\hline $\mathrm{GS}>8 \mathrm{~mm}(\%)$ & - & -0.227 & -0.145 & -0.015 & 0.080 \\
\hline GS $8-4 \mathrm{~mm}(\%)$ & $-0.552^{\mathrm{a}, *}$ & 0.004 & 0.066 & -0.165 & -0.042 \\
\hline GS 4-2 mm (\%) & $0.110^{\mathrm{a}}$ & 0.016 & 0.029 & -0.224 & -0.042 \\
\hline GS $2-0.063 \mathrm{~mm}(\%)$ & $0.439^{\mathrm{a}, *}$ & 0.195 & -0.014 & 0.050 & -0.115 \\
\hline $\mathrm{GS}<0.063 \mathrm{~mm}(\%)$ & $0.498^{\mathrm{a}, *}$ & 0.094 & 0.097 & $0.334 *$ & $0.261^{*}$ \\
\hline Temperature $\left({ }^{\circ} \mathrm{C}\right)$ & $0.441 *$ & $0.545^{*}$ & $0.657^{*}$ & $0.757^{*}$ & $0.665^{*}$ \\
\hline BA (cells $g^{-1}$ dry wt) & $0.272 *$ & $0.412 *$ & $0.290 *$ & 0.244 & $0.471^{*}$ \\
\hline
\end{tabular}

Water content (WC) is expressed as \% of dry wt, soil-sediment temperatures were measured in situ, organic matter (OM) content of two size fractions and total content are expressed as $\mathrm{g}$ AFDM kg${ }^{-1}$ dry wt, and classes of grain size distribution (GS) are expressed in \% of the sum of all size fractions. Significant correlations $(p<0.05)$ are indicated by asterisks

$n$ number of samples in each habitat

${ }^{a}$ Values recalculated after adoption of $54.4 \%$ to GS $>8 \mathrm{~mm}(\%)$ from the gravel habitat (analysis of 60 gravel samples)

2010). Further, the contribution of root respiration to total soil respiration can range from 10 to $90 \%$ (Hanson et al. 2000), which also must be taken into account. The influence of root respiration is most likely highest in pasture/grassland habitats and lowest in gravel habitats. Consequently, pasture/grassland habitats are influenced by multiple components of respiration. These circumstances may explain that the respiration of pasture/grassland did not correlate either with bacterial abundance or with organic matter. The lowest respiration was measured in gravel habitats. Measured values were higher than those in gravels of the Soča floodplain in Slovenia (authors; unpublished data), lower than those in gravels in the Tagliamento floodplain of Italy (Doering et al. 2011), and similar to those in cold desert soils of the Colorado Plateau (Fernandez et al. 2006). Nevertheless, we found a similar respiration pattern among the habitats in the Urbach floodplain similar to the Tagliamento and Soča floodplain, suggesting similar functional patterns in floodplains ranging from the European Mediterranean to subalpine region.

In this study, respiration displayed high spatial variability within respective floodplain habitats. In gravel habitats, this spatial patchiness in respiration was likely caused by an uneven organic matter distribution along the floodplain. The patchiness in respiration within islands, mature forest and pasture/grassland habitats was likely due to the spatial heterogeneity in vegetation cover, successional stage and root distribution that reflect a patchy distribution of nutrients and microorganisms (Xu and Qi 2001). For instance, the variation in respiration is related to the spatial distribution of microorganisms processing patches of organic matter resource pools (van Gestel et al. 1996). This patchiness in respiration within habitats also was documented in floodplain habitats of the Tagliamento river, Italy (Doering et al. 2011) and Soča river, Slovenia (authors; unpublished data).

Bacterial abundance and enzyme activities showed a similar pattern as respiration between floodplain habitats, with low abundances and activity in stream and gravel habitats and higher abundances and activity in mature forest, islands and pasture/grassland habitats. Enzyme activity also had high patchiness within respective habitats. Regardless, enzymatic activity patterns correlated best with WC and smaller particle size fractions of the substratum. It has been shown that stream sediment substratum with low uniformity but small grain sizes are positively associated with specific enzymatic activities (Freimann et al. 2013a). The underlying mechanisms are likely to be linked to the potential larger biofilm surface within a given volume of substratum as well as solute transportation guaranteeing continuous supply of organic matter. This result is in concordance with the relative low enzyme activities found in stream and gravel habitats characterized by coarser substratum. Nonetheless, esterase (EST) and endopeptidase (END) played a significant role here and accounted for a large part of the total enzymatic activities. This prevalence of END and EST has been linked to the importance of gathering carbon and nitrogen from lipids and peptides (Freimann et al. 2013a). Islands, mature forest and pasture/grassland habitats had significantly higher activities 
for the other enzymes with no specific enzyme(s) clearly distinguishing a habitat type. Carbon and nitrogen are likely to be introduced by plant biomass. BET, for example, can be triggered by cellulose inputs (Shewale 1982; Sinsabaugh et al. 1991). Enzyme activities showed similar patterns between habitat types in the Soča floodplain, Slovenia, although with somewhat higher values (authors, unpublished data). Unfortunately, there are no other studies that we are aware of, that examined enzyme activities between different floodplain habitats, with most being done solely in aquatic (Burns and Ryder 2001; Romani et al. 2013) or terrestrial habitats (Sinsabaugh et al. 2008; Zeglin et al. 2013). Additional research is clearly needed to better understand the relationship of microbial enzymes activities with origin, timing, quality and quantity of nutrient inputs.

Except for enzyme activities, all measured variables showed lower values in October relative to May and August, reflecting the lower soil-sediment temperatures at that time. For example, the high respiration in pasture/grassland habitats in May can be explained by an active growing season (i.e. root respiration). Seasonality in respiration was much lower in this study compared to the Tagliamento floodplain (Doering et al. 2011), and was lacking in stream and gravel habitats. Local hydrology via high flows may mask seasonal changes in respiration due to the flushing effects (increased mobility of bed sediments) of floods that reduce organic resources and ecosystem respiration in river channels (Uehlinger et al. 2003). Although also affected by high flows, islands, mature forest and pasture/grassland habitats show degrees of seasonality in ecosystem metabolism that reflect their general soilsediment stability relative to that of river beds (Arscott et al. 2002). There was seasonality of enzymatic activity patterns in the stream and gravel habitats (see dispersion ellipses in Fig. S3 in supplementary material).

Respiration was strongly correlated with temperature in islands, mature forest and pasture/grassland habitats. Temperature has been shown to be a major driver of ecosystem metabolism in other studies (Gansert 1994; Buchmann 2000), most likely by affecting the abundance and composition of microbial assemblages (Rinklebe and Langer 2006; Kant et al. 2011). Temperature also influenced enzymatic activity patterns, although being less distinct. It is likely that respiration is driven by an interactive effect where temperature regulates specific protein kinetics (and thus respiration) rather than constraining enzymatic activity patterns (Sizer 2006). Respiration was less correlated with temperature in stream and gravel habitats, probably being related to flood disturbance that mobilizes and flushes bed sediments, and thus reducing ecosystem metabolism (Jones et al. 1995; Uehlinger 2006). This hydrological effect of high flows in the active river channel is also seen in the greater grain sizes and lower amounts of organic matter in stream and gravel habitats than in the other floodplain habitats, as shown in other studies (Schimel et al. 1994; Randerson et al. 1996).

Soil-sediment water content (WC) can also influence respiration (Davidson et al. 2000; Xu and Qi 2001), but was not correlated in this study (Bridgham and Richardson 1992). A water content of about $20 \%$ (\% of maximal water holding capacity; grain size $<2 \mathrm{~mm}$ ) was found to be the critical threshold for bacterial carbon production (Amalfitano et al. 2008). However, maximal water holding capacity was not assessed in the present study. Hence, an explanation for the missing correlation between respiration and WC could be that the WC in our floodplain habitats was always above the critical threshold. Nevertheless, a major characteristic of floodplains is that some habitats are frequently and regularly flooded during the annual cycle for relatively short periods of time (Baldwin and Mitchell 2000). This flooding has a large influence on respiration patterns in these habitats. For example, Rinklebe and Langer (2006) observed lower microbial biomass but higher basal respiration in long-term submerged soils in contrast to short-time flooded ones. Furthermore, it has been observed that short-term inundations cause an almost immediate change in carbon turnover and microbial driven processes such as microbial respiration and enzymatic degradation rates (Wilson et al. 2011).

There was a longitudinal trend in some measured variables that likely reflect coarse-scale patterns in hydrology and organic matter inputs. For example, the highest respiration in gravel habitats was in zone 3 , and this zone is affected by avalanches that deliver large quantities of organic matter from east-facing side-slopes (compare Williams 2014). There were also higher respiration values in zone 4 , for islands in particular. In general, zone 4 had a higher number of islands than the other zones. Most floodplain islands are created through channel avulsion that dissects floodplain forests or through vegetation development on gravel-bars within the active river (Gurnell et al. 2001). Islands derived from the latter have a graded tree age structure while those from forest dissection have a relatively even or irregular patchy tree age structure (Gurnell et al. 2001). The two island types also differ in stability and soil structure, typically being greatest in dissected forest islands. Dissected forest islands predominate in zone 4 and may explain the higher respiration of these islands relative to the other zones.

The upper floodplain comprising zones 1-3 were characterized by hydrological downwelling conditions, whereas zone 4 in the lower floodplain had neutral to slight upwelling conditions. The degree of hydrologic downwelling and upwelling can be caused by floods or by seasonal changes in baseflow and discharge (Valett 1993; Valett et al. 1996). The local upwelling of hyporheic water 
increases water availability and nutrient delivery to floodplain soil-sediments and vegetation (Harner and Stanford 2003), which also may explain the generally higher respiration in zone 4 , in island habitats in particular.

Floodplain islands are threatened habitats in most regulated rivers (Tockner et al. 2010b). Hence, the finding of this study that floodplain metabolism was strongly coupled with island presence suggests a major role of islands in floodplain functioning. Others have noted the importance of islands in organic matter production (Tockner et al. 2010a; Langhans et al. 2013) and as "hot spots" for ecosystem processes (Langhans et al. 2006; Doering et al. 2011). Intact floodplains with their characteristic heterogeneous structure provide numerous ecosystem services and floodplain islands clearly are important towards sustaining these services. For instance, the observed CNP preferences in the potential enzyme activity results indicate high process heterogeneity, and therefore the capacity to efficiently turn over different nutrients. Based on our results, we infer that floodplain regulation, i.e. habitat homogenization, would reduce the effective functioning of these ecosystems, thereby placing constraints on important ecosystem services. Our results contribute to a better understanding of floodplain ecosystem functioning, and are useful to identify stressor-driven changes due to, e.g., climate change, water abstraction and channelization. This fundamental knowledge about the structure and function of floodplain ecosystems is essential for their successful protection and restoration. Thereby, functional measures such as respiration can be useful indicators for assessments of floodplain ecosystems.

Acknowledgments Many thanks to Tom Gonser, Simone Blaser, Marta Reyes, Sara Hasler, Raphael Zimmermann, Thomas Hartmann, Markus Bodmer, and Martina Blaurock for their support in the field and laboratory. Lara Schmidlin provided useful comments on an early stage of the manuscript, which is much appreciated. Simone Langhans supported the progress of this manuscript with fruitful and helpful discussions and comments, which are highly appreciated. This research was funded by the Kraftwerke Oberhasli AG (KWO AG) and the Swiss Federal Office for the Environment (FOEN). Finally, we thank the anonymous reviewers for constructive inputs that improved the manuscript.

\section{Compliance with ethical standards}

Conflict of interest All authors declare to not have any potential conflict of interest.

\section{References}

Allison SD, Gartner T, Holland K, Weintraub M, Sinsabaugh RL (2007) Soil enzymes: linking proteomics and ecological process. In: Hurst CJ, Knudsen GR, McInerney MJ, Stetzenbach LD, Walter MV (eds) Manual of Environmental Microbiology, 3rd edn. ASM Press, pp 704-711
Amalfitano S, Fazi S, Zoppini A, Caracciolo AB, Grenni P, Puddu A (2008) Responses of benthic bacteria to experimental drying in sediments from Mediterranean temporary rivers. Microbial Ecol 55:270-279

Andrews JA, Schlesinger WH (2001) Soil $\mathrm{CO}_{2}$ dynamics, acidification, and chemical weathering in a temperate forest with experimental $\mathrm{CO}_{2}$ enrichment. Glob Biogeochem Cycle 15:149-162

Arscott DB, Tockner K, van der Nat D, Ward JV (2002) Aquatic habitat dynamics along a braided alpine river ecosystem (Tagliamento River, Northeast Italy). Ecosystems 5:802-814. doi:10.1007/s10021-002-0192-7

Baldwin DS, Mitchell AM (2000) The effects of drying and reflooding on the sediment and soil nutrient dynamics of lowland river-floodplain systems: a synthesis. Regul Rivers Res Manag 16:457-467

Bass AM, O'Grady D, Leblanc M, Tweed S, Nelson PN, Bird MI (2014) Carbon dioxide and methane emissions from a wet-dry tropical floodplain in Northern Australia. Wetlands 34:619-627. doi:10.1007/s13157-014-0522-5

Baxter CV, Hauer FR, Woessner WW (2003) Measuring groundwater-stream water exchange: new techniques for installing minipiezometers and estimating hydraulic conductivity. Trans Am Fish Soc 132:493-502

Benner R, Opsahl S, ChinLeo G, Richey JE, Forsberg BR (1995) Bacterial carbon metabolism in the Amazon River system. Limnol Oceanogr 40:1262-1270

Bennion H, Carvalho L, Sayer CD, Simpson GL, Wischnewski J (2011) Identifying from recent sediment records the effects of nutrients and climate on diatom dynamics in Loch Leven. Freshw Biol 57:2015-2029. doi:10.1111/j.1365-2427.2011. 02651.x

Boulton AJ, Datry T, Kasahara T, Mutz M, Stanford JA (2010) Ecology and management of the hyporheic zone: streamgroundwater interactions of running waters and their floodplains. J N Am Benthol Soc 29:26-40. doi:10.1899/08-017.1

Bridgham SD, Richardson CJ (1992) Mechanisms controlling soil respiration $\left(\mathrm{CO}_{2}\right.$ and $\left.\mathrm{CH}_{4}\right)$ in southern peatlands. Soil Biol Biochem 24:1089-1099

Brunke M, Gonser T (1997) The ecological significance of exchange processes between rivers and groundwater. Freshw Biol 37:1-33. doi:10.1046/j.1365-2427.1997.00143.x

Buchmann N (2000) Biotic and abiotic factors controlling soil respiration rates in Picea abies stands. Soil Biol Biochem 32:1625-1635

Buesing N, Gessner MO (2002) Comparison of detachment procedures for direct counts of bacteria associated with sediment particles, plant litter and epiphytic biofilms. Aquat Microb Ecol 27:29-36

Burns A, Ryder DS (2001) Response of bacterial extracellular enzymes to inundation of floodplain sediments. Freshw Biol 46:1299-1307

Chevan A, Sutherland M (1991) Hierarchical partitioning. Am Stat 45:90-96

Clarke KR, Gorley RN (2006) PRIMER v6: User manual/tutorial. In: PRIMER-E. Plymouth UK, p 91 ( p 192)

Datry T, Corti R, Belletti B, Piegay H (2014) Ground-dwelling arthropod communities across braided river landscape mosaics: a Mediterranean perspective. Freshw Biol 59:1308-1322. doi:10. $1111 /$ fwb. 12350

Davidson EA, Verchot LV, Cattanio JH, Ackerman IL, Carvalho JEM (2000) Effects of soil water content on soil respiration in forests and cattle pastures of eastern Amazonia. Biogeochemistry 48:53-69

Dick RP (1994) Soil enzyme activities as indicators of soil quality. In: Doran JV, Coleman DC, Bezdicek DF, Steward BA (eds) Defining soil quality for a sustainable environment, vol 35. 
SSSA Special Publication, Madison, pp 107-124. doi:10.2136/ sssaspecpub35.c17

Dilly O (2001) Microbial respiratory quotient during basal metabolism and after glucose amendment in soils and litter. Soil Biol Biochem 33:117-127

Doering M, Uehlinger U, Ackermann T, Woodtli M, Tockner K (2011) Spatiotemporal heterogeneity of soil and sediment respiration in a river-floodplain mosaic (Tagliamento, NE Italy). Freshw Biol 56:1297-1311. doi:10.1111/j.1365-2427.2011.02569.x

Doering M, Blaurock M, Robinson CT (2012) Landscape transformation of an Alpine floodplain influenced by humans: historical analyses from aerial images. Hydrol Process 26:3319-3326. doi:10.1002/hyp.8374

Fernandez DP, Neff JC, Belnap J, Reynolds RL (2006) Soil respiration in the cold desert environment of the Colorado Plateau (USA): abiotic regulators and thresholds. Biogeochemistry 78:247-265. doi:10.1007/s10533-005-4278-0

Freimann R, Burgmann H, Findlay SEG, Robinson CT (2013a) Bacterial structures and ecosystem functions in glaciated floodplains: contemporary states and potential future shifts. ISME J 7:2361-2373. doi:10.1038/ismej.2013.114

Freimann R, Burgmann H, Findlay SEG, Robinson CT (2013b) Response of lotic microbial communities to altered water source and nutritional state in a glaciated alpine floodplain. Limnol Oceanogr 58:951-965. doi:10.4319/lo.2013.58.3.0951

Gansert D (1994) Root respiration and its importance for the carbon balance of beech saplings (Fagus-Sylvatica L) in a montane beech forest. Plant Soil 167:109-119

Grimm NB, Fisher SG (1984) Exchange between interstitial and surface-water-implications for stream metabolism and nutrient cycling. Hydrobiologia 111:219-228

Grömping U (2006) Relative importance for linear regression in R: the package relaimpo. J Stat Softw 17:1-27

Gurnell AM et al (2001) Riparian vegetation and island formation along the gravel-bed Fiume Tagliamento, Italy. Earth Surf Process Landf 26:31-62

Hammes FA, Egli T (2005) New method for assimilable organic carbon determination using flow-cytometric enumeration and a natural microbial consortium as inoculum. Environ Sci Technol 39:3289-3294

Han GX, Zhou GS, Xu ZZ, Yang Y, Liu JL, Shi KQ (2007) Biotic and abiotic factors controlling the spatial and temporal variation of soil respiration in an agricultural ecosystem. Soil Biol Biochem 39:418-425. doi:10.1016/j.soilbio.2006.08.009

Hanson PJ, Edwards NT, Garten CT, Andrews JA (2000) Separating root and soil microbial contributions to soil respiration: a review of methods and observations. Biogeochemistry 48:115-146

Harner MJ, Stanford JA (2003) Differences in cottonwood growth between a losing and a gaining reach of an alluvial floodplain. Ecology 84:1453-1458. doi:10.1890/0012-9658(2003)084[1453: dicgba]2.0.co;2

Iovieno P, Morra L, Leone A, Pagano L, Alfani A (2009) Effect of organic and mineral fertilizers on soil respiration and enzyme activities of two Mediterranean horticultural soils. Biol Fert Soils 45:555-561. doi:10.1007/s00374-009-0365-Z

Jones JB, Fisher SG, Grimm NB (1995) Vertical hydrologic exchange and ecosystem metabolism in a Sonoran Desert stream. Ecology 76:942-952

Junk WJ, Bayley PB, Sparks RE (1989) The flood pulse concept in river-floodplain systems. Can Spec Publ Fish Aquat Sci 106:110-127

Kant R, Ghosh C, Singh L, Tripathi N (2011) Survival and sustainability. Springer, Berlin, pp 151-161

Kastovska E, Santruckova H, Picek T, Vaskova M, Edwards KR (2010) Direct effect of fertilization on microbial carbon transformation in grassland soils in dependence on the substrate quality. J Plant Nutr Soil Sci 173:706-714. doi:10.1002/jpln. 200900013

Kosugi $Y$ et al (2007) Spatial and temporal variation in soil respiration in a Southeast Asian tropical rainforest. Agric For Meteorol 147:35-47. doi:10.1016/j.agrformet.2007.06.005

Langhans SD, Tiegs SD, Uehlinger U, Tockner K (2006) Environmental heterogeneity controls organic-matter dynamics in riverfloodplain ecosystems. Pol J Ecol 54:675-680

Langhans SD, Richard U, Rueegg J, Uehlinger U, Edwards P, Doering M, Tockner K (2013) Environmental heterogeneity affects input, storage, and transformation of coarse particulate organic matter in a floodplain mosaic. Aquat Sci 75:335348

Logue JB, Robinson CT, Meier C, Van der Meer JR (2004) Relationship between sediment organic matter, bacteria composition, and the ecosystem metabolism of alpine streams. Limnol Oceanogr 49:2001-2010

Lorang MS, Whited DC, Hauer FR, Kimball JS, Stanford JA (2005) Using airborne multispectral imagery to evaluate geomorphic work across floodplains of gravel-bed rivers. Ecol Appl 15:1209-1222. doi:10.1890/03-5290

Moorhead DL, Sinsabaugh RL (2006) A theoretical model of litter decay and microbial interaction. Ecol Monogr 76:151-174

Nakano S, Murakami M (2001) Reciprocal subsidies: dynamic interdependence between terrestrial and aquatic food webs. Proc Natl Acad Sci USA 98:166-170

Paetzold A, Schubert CJ, Tockner K (2005) Aquatic terrestrial linkages along a braided river: riparian arthropods feeding on aquatic insects. Ecosystems 8:748-759

Parvathi A, Radhakrishnan S, Sajila MP, Jacob B (2011) Study of changes in bacterial and viral abundance in formaldehyde-fixed water samples by epifluorescence microscopy. Environ Monit Assess 177:227-231

Qi Y, Xu M (2001) Separating the effects of moisture and temperature on soil $\mathrm{CO}_{2}$ efflux in a coniferous forest in the Sierra Nevada mountains. Plant Soil 237:15-23

Randerson JT, Thompson MV, Malmstrom CM, Field CB, Fung IY (1996) Substrate limitations for heterotrophs: implications for models that estimate the seasonal cycle of atmospheric $\mathrm{CO}_{2}$. Glob Biogeochem Cycle 10:585-602

R-Development-Core-Team (2014) R: A language and environment for statistical computing. R Foundation for Statistical Computing, Vienna, Austria. ISBN 3-900051-07-0. http://www.R-project.org/

Rinklebe J, Langer U (2006) Microbial diversity in three floodplain soils at the Elbe River (Germany). Soil Biol Biochem 38:2144-2151. doi:10.1016/j.soilbio.2006.01.018

Robinson C, Doering M (2012) Spatial patterns in macroinvertebrate assemblages in surface-flowing waters of a glacially-influenced floodplain. Aquat Sci. doi:10.1007/s00027-012-0283-2

Romani AM (2000) Characterization of extracellular enzyme kinetics in two Mediterranean streams. Arch Hydrobiol 148:99-117

Romani AM et al (2013) Microbial biofilm structure and organic matter use in mediterranean streams. Hydrobiologia 719:43-58. doi:10.1007/s10750-012-1302-y

Schimel DS et al (1994) Climatic, edaphic, and biotic controls over storage and turnover of carbon in soils. Glob Biogeochem Cycle 8:279-293

Shewale JG (1982) Beta-glucosidase-its role in cellulase synthesis and hydrolysis of cellulose. Int J Biochem 14:435-443. doi:10. 1016/0020-711x(82)90109-4

Sieczko A, Peduzzi P (2014) Origin, enzymatic response and fate of dissolved organic matter during flood and non-flood conditions in a river-floodplain system of the Danube (Austria). Aquat Sci $76: 115-129$

Singh JS, Gupta SR (1977) Plant decomposition and soil respiration in terrestrial ecosystems. Bot Rev 43:449-528 
Sinsabaugh RL, Antibus RK, Linkins AE (1991) An enzymatic approach to the analysis of microbial activity during plant litter decomposition. Agric Ecosyst Environ 34:43-54

Sinsabaugh RL et al (2008) Stoichiometry of soil enzyme activity at global scale. Ecol Lett 11:1252-1264. doi:10.1111/j.1461-0248. 2008.01245.x

Sinsabaugh RL, Hill BH, Shah JJF (2009) Ecoenzymatic stoichiometry of microbial organic nutrient acquisition in soil and sediment. Nature 462:795-798. doi:10.1038/Nature08632

Sizer IW (2006) Effects of temperature on enzyme kinetics. Advances in enzymology and related areas of molecular biology. Wiley, Hoboken, pp 35-62

Stanford JA, Lorang MS, Hauer FR (2005) The shifting habitat mosaic of river ecosystems. Proc Int Soc Limnol 29:123-136

Stevenson FJ (1986) Cycles of soil: carbon, nitrogen, phosphorus, sulfur, micronutrients, 2nd edn. Wiley, Hoboken

Tockner K, Malard F, Ward JV (2000) An extension of the flood pulse concept. Hydrol Process 14:2861-2883

Tockner K, Lorang MS, Stanford JA (2010a) River flood plains are model ecosystems to test general hydrogeomorphic and ecological concepts. River Res Appl 26:76-86. doi:10.1002/rra.1328

Tockner K, Pusch M, Borchardt D, Lorang MS (2010b) Multiple stressors in coupled river-floodplain ecosystems. Freshw Biol 55:135-151. doi:10.1111/j.1365-2427.2009.02371.x

Tonolla D, Acuna V, Uehlinger U, Frank T, Tockner K (2010) Thermal heterogeneity in river floodplains. Ecosystems 13:727-740. doi:10.1007/s10021-010-9350-5

Uehlinger U (2006) Annual cycle and inter-annual variability of gross primary production and ecosystem respiration in a floodprone river during a 15-year period. Freshw Biol 51:938-950. doi:10. 1111/j.1365-2427.2006.01551.x

Uehlinger U, Naegeli M, Fisher SG (2002) A heterotrophic desert stream? The role of sediment stability. West North Am Nat 62:466-473

Uehlinger U, Kawecka B, Robinson CT (2003) Effects of experimental floods on periphyton and stream metabolism below a high dam in the Swiss Alps (River Spol). Aquat Sci 65:199-209. doi:10.1007/s00027-003-0664-7

Valett HM (1993) Surface-hyporheic interactions in a sonoran desert stream-hydrologic exchange and diel periodicity. Hydrobiologia 259:133-144. doi:10.1007/bf00006593
Valett HM, Morrice JA, Dahm CN, Campana ME (1996) Parent lithology, surface-groundwater exchange, and nitrate retention in headwater streams. Limnol Oceanogr 41:333-345

van der Nat D, Tockner K, Edwards PJ, Ward JV, Gurnell AM (2003) Habitat change in braided flood plains (Tagliamento, NE-Italy). Freshw Biol 48:1799-1812

van Gestel M, Merckx R, Vlassak K (1996) Spatial distribution of microbial biomass in microaggregates of a silty-loam soil and the relation with the resistance of microorganisms to soil drying. Soil Biol Biochem 28:503-510. doi:10.1016/0038-0717(95)00192-1

Wallenius K, Rita H, Simpanen S, Mikkonen A, Niemi RM (2010) Sample storage for soil enzyme activity and bacterial community profiles. J Microbiol Methods 81:48-55. doi:10.1016/j.mimet. 2010.01.021

Williams TJ (2014) Estimating organic carbon on avalanche paths in Glacier National Park, Montana. MA (Master of Arts) Thesis, University of Iowa

Wilson JS, Baldwin DS, Rees GN, Wilson BP (2011) The effects of short-term inundation on carbon dynamics. Microbial community structure and microbial activity in floodplain soil, River Res Appl 27

Winkler JP, Cherry RS, Schlesinger WH (1996) The Q(10) relationship of microbial respiration in a temperate forest soil. Soil Biol Biochem 28:1067-1072. doi:10.1016/0038-0717(96)00076-4

$\mathrm{Xu} \mathrm{M}$, Qi Y (2001) Soil-surface $\mathrm{CO}_{2}$ efflux and its spatial and temporal variations in a young ponderosa pine plantation in northern California. Glob Change Biol 7:667-677

Zar JH (1984) Biostatistical analysis. Prentice-Hall Inc., Englewood Cliffs

Zeglin LH et al (2013) Altered precipitation regime affects the function and composition of soil microbial communities on multiple time scales. Ecology 94:2334-2345. doi:10.1890/122018.1

Zimmermann R, Iturriaga R, Beckerbirck J (1978) Simultaneous determination of total number of aquatic bacteria and number thereof involved in respiration. Appl Environ Microbiol 36:926-935 